\title{
Growing characteristics of apple cultivars and canopies
}

\author{
Csihon, Á., Holb, I.J. \& Gonda, I. \\ University of Debrecen, Faculty of the Agricultural and Food Sciences and Environmental Management, \\ Institute of Horticulture, 138. Böszörményi str., Debrecen, H-4032, Hungary
}

\begin{abstract}
Summary: In our study we aimed to evaluate the growing characteristics of new prospective apple cultivars and their canopies. The following parameters were measured: i) thickness of the trunk and the central leader, ii) ratio of the trunk thickness and the basic branches (Zahnindexes), iii) number of the branches of the central leader, and iv) thickness of the branches of the central leader. The main branches of the trunk and the central leader tend to over thickening in the case of cvs 'Red Idared', 'Wilton's Red Jonaprince' and 'Jeromine'. The density of the branches of certain parts of the canopy was too low for cvs 'Crimson Crisp', 'Wilton's Red Jonaprince', 'Fuji September Wonder' and 'Red Idared'. The density of the branches of certain parts of the canopy was too high for cvs 'Gala Venus Fengal', 'Wilton's Red Jonaprince' and 'Red Cap Valtod'. Relationship was found between the tapering dynamics of the central axis and the thickness of the main branches, which was stronger in super spindle canopies than in slender spindle crown forms.
\end{abstract}

Keywords: apple cultivars, canopies, growing characteristics

\section{Introduction}

Apple is the most important fruit of the temperate zone, as belongs to the most intensively breeded fruits. The new cultivars/mutants are characterized by larger fruit size, higher fruit surface color, better taste, higher genetic stability or resistant ability. These kind of characteristics also those that are emphasized the most in the different cultivar evaluation studies. Namely the data related with the yields and the fruit quality are well presented in the international studies of the cultivar descriptions, but the growing and the producing characteristics of the cultivars are given only superficially. The growing habits of the trees, the specialities of the canopy training or the necessity of the specific pruning interventions are not detailed, although these factors can also determine the success of the production. However, thanks to the intensity growing, namely to the more simple canopy structures there are more possibilities to compare the vegetative parameters of the each crown forms (e.g. tapering dynamics of the central axis, number of the branches, thickness of the branches, etc.), which can ensure useful information for the producers during the training and the maintaining of the trees.

In the intensive orchards of the present days the slender spindle and the super spindle canopies are the most used. The slender spindle started to spread thanks to Wertheim (1968) works. In Hungary initially the studies of Gonda (1995a,b, 1997) examined the possibilities of its application.

The cropping surface of the slender spindle is made up by 3-4 permanent basic branches and 1-3 years old young branches of the central leader. The canopy with optimal structure (isosceles triangle or conical shape) is characterized by branches with thickness decreasing going bottom-up (Gonda, 2004). Nevertheless according to the practical experiences a part of the basic branches can over thicken and reach excessive length under growth inspiring circumstances. This problem occurs mainly in the case of the precipitous branches. Cutting back these branches can not be the solution, because it would result in excessive growth (Gonda \& Fülep, 2011).

The problem of the maintaining the basic branches was also emphasized by Corelli \& Sansavini (1989), when the slender spindle just started to spread. According to their opinion the permanent basic branches can be the „Achilles point" of the training system, as the continuously thickening branches can create shadow zone, which can decrease the fruit quality.

The difficulties of the canopy maintenance of the slender spindle had already anticipated the birth of a new canopy with more simple structure.

The first super spindle orchards were developed in the Bodensee region of Germany at the end of the 80's. This system utilizes super high tree densities to obtain the expected attributes of high and early yields, less manual work, less chemical input, high picking output resulting in low production cost per man hour of labor and the possibility to introduce quickly new valuable varieties into the market (Weber, 1998).

The super spindle canopy makes possibly to create and maintain similar thick branches on the dominant central in its full length during the all life of the trees. These kinds of trees are rather cylindrical then conical, as the lateral dimension of the canopy does not permit the upward narrowing without cropping surface loss (Gonda \& Fülep, 2011).

To create and maintain the canopies of the intensive orchards Zahn (1975) determined the optimal thickness ratio between the central leader and the branches, which can be 
controlled by pruning well. Based on his research the thickness of the branches on the trunk must be under the half of the trunk thickness measured directly below the branch. Gonda \& Fülep (2011) claims that the optimal value depends on the cultivars, so it is possibly to vary from the ratio 0.5 . In the case of the cultivars with weaker growth (cvs 'Idared' and 'Red Delicious' spurs) the optimal is $0.2-0.3$. For the cv 'Gala' the 0.3-0.4 can be named favorable, for the cv 'Jonagold' and the cv 'Red Delicious' the $0.4-0.5$ values are optimal.

The aim of this study was to evaluate the vegetative performance of new apple cultivars originated from abroad to serve useful information for the practice.

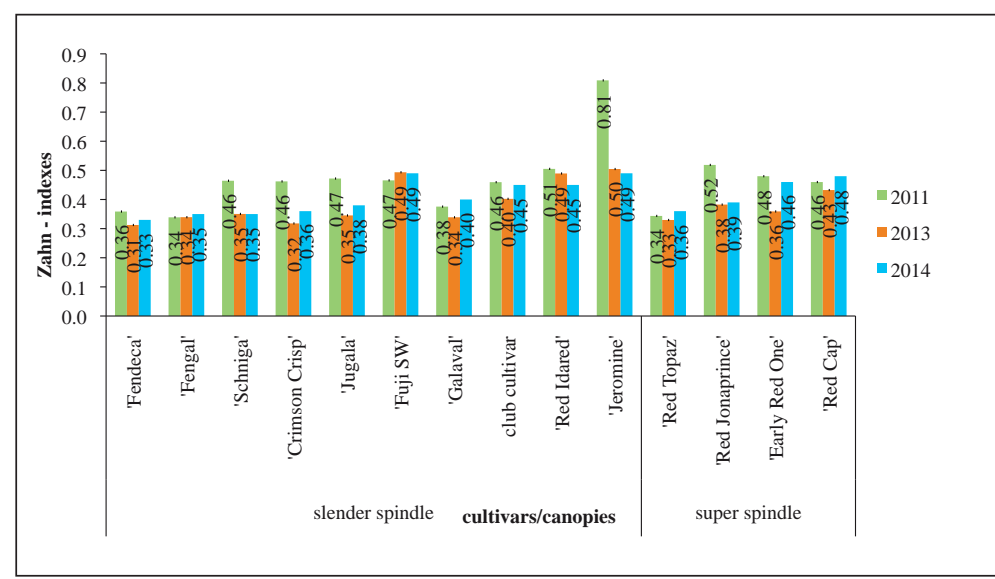

Figure 1: Zahn-indexes of the main branches of the apple cultivars (Nyírbátor, 2011, 2012, and 2014).

\section{Materials and method}

The experimental orchard is located in the Nyírség region, in Nyírbátor (F.N. Fruit Ltd.), $55 \mathrm{~km}$ far from Debrecen. The apple cultivars were planted in autumn of 2010 and in spring of 2011, so all the cultivars developed four vegetation period so far. The rootstock of the scions is M9 ensuring the dwarfing vigour. The distance between the rows is 3.85 meter. In the case of the cultivars with slender spindle (cvs 'Gala Venus Fengal', 'Gala DecarliFendeca', 'Galaval', 'Jugala', 'Gala Schnitzer (S) Schniga', 'Jeromine', 'Crimson Crisp (Co-op 39)', 'Red Idared', 'Fuji September Wonder' and club cultivar) the plant-toplant distance is 1 meter. Between the cultivars with super spindle canopy (cvs 'Red Cap Valtod (S)', 'Early Red One', 'Red Topaz' and 'Wilton's Red Jonaprince') 0.5 meter distance was created.

In the orchard the trees are fixed to trellis system. The high of the trellis is 2.7 meter, which makes the possibility to train the optimal 3.0-3.5 meter high trees. The water supply is solved with dropping irrigation system. The plant protection is carried in accordance with the integrated management principles. The pruning is performed at the end of the winter.

To describe the growing characteristics of the cultivars 7 trees were signed per each cultivars. In this study the following parameters were measured: i) thickness of the trunk and the central leader, ii) ratio of the trunk thickness and the basic branches (Zahn-indexes), iii) number of the branches of the central leader, and iv) thickness of the branches of the central leader.

\section{Results}

Majority of the cultivars the ratio of the trunk thickness and the basic branches (Zahn-indexes) was under or around the critical 0.5 value (Figure 1). One year after the planting the cv 'Jeromine' presented very high, 0.8 value. On the three-four years old trees it decreased notably. Similar decreasing tendency can be seen also with other cultivars (cvs 'Fendeca', 'Schniga', 'Crimson Crisp', 'Jugala', 'Red Jonaprince', 'Red Idared' and 'Jeromine'). It means, that the thickening of the trunk and the central leader was stronger, than the thickening of basic branches, or rather the older and thicker branches were removed during the winter pruning.

Based on the Zahn-indexes the examined cultivars can be classified the next ways: i) the one year old and the four year old trees also can be described with low indexes (under 0.4): cvs 'Fendeca', 'Fengal', 'Galaval' and 'Red Topaz', ii) the one year old trees have medium values (0.4-0.5), the four years old trees have low values (under 0.4): cvs 'Crimson Crisp', 'Jugala' and 'Schniga', iii) the one year old and the four years old trees also can be described with medium indexes (0.4-0.5): cvs 'Red Cap', 'Fuji SW', 'Early Red One' and club cultivar, and iv) the one year old trees have high Zahn-indexes (above 0.5), which later decreases, but still can be to high: cvs 'Red Idared', 'Jeromine' and 'Red Jonaprince'.

The knowledge of these parameters can help notably the training and maintaining pruning strategy of the trees.

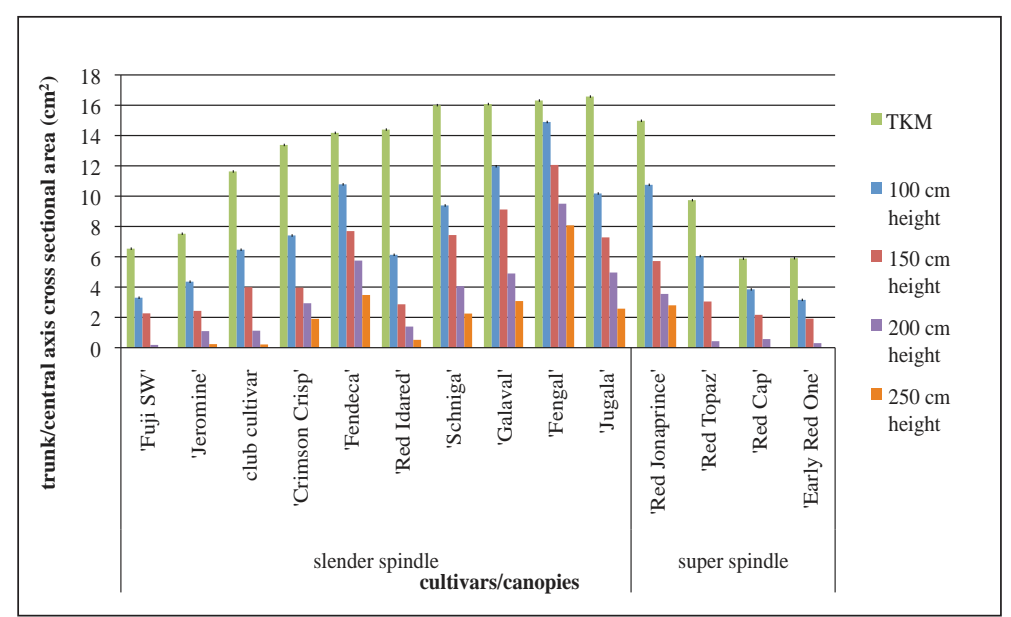

Figure 2: Thickness of the trunk and the central leader in different height zones $\left(\mathrm{cm}^{2}\right)$ (Nyírbátor, 2014). 
The thickness of the trunk and the central leader (Figure 2), namely the tapering dynamics of the central leader can determine notably the available tree height. The vigorous 'Gala' mutants can be described with high central leader dominance, as above the thick trunk the leader starts to taper slightly. The cv 'Red Idared' displays the opposite phenomenon, namely above the thick trunk the leader starts to taper rapidly. It can be named unfavorable peculiarity, as the possibility to reach the optimal $3.0-3.5 \mathrm{~m}$ tree height is lower.

ccording to the thickness of the trunk and the central leader the cultivars can be classified to the next groups: i) high trunk, and low central leader thickness: cv 'Red Idared', ii) high trunk, and medium central leader thickness: cvs 'Schniga', 'Galaval', 'Jugala' and 'Red Jonaprince', iii) high trunk, and high central leader thickness: cvs 'Fengal' and 'Fendeca', iv) medium trunk, and medium central leader thickness: cvs 'Crimson Crisp', 'Red Topaz' and club cultivar, and v) low trunk, and low central leader thickness: cvs 'Fuji SW', 'Jeromine', 'Red Cap' and 'Early Red One'.

In the case of the cvs 'Early Red One', 'Crimson Crisp' and 'Red Jonaprince' the distribution of the main branches shows decreasing tendency from to upper to the higher regions (Figure 3). The weaker ramification of the higher zones of the latter two cultivars can be considered unfavorable.

Based on the distribution of the brunches on the central leader the cultivars can be sorted to the next groups: i) the canopy is ramified uniformly: cvs 'Schniga', Fengal', 'Fendeca', 'Jugala', 'Galaval', club cultivar, 'Jeromine', 'Early Red One' and 'Fuji SW', ii) the density of the branches of certain parts of the canopy can be too low: cvs 'Crimson Crisp' and 'Red Jonaprince', and iii) the density of the branches of certain parts of the canopy can be too high: cvs 'Red Topaz', 'Red Jonaprince', 'Red Cap' and 'Red Idared'.

Regarding the thickness of the branches of the central leader (Figure 4) most of the cultivars showed the peculiarity of the spindle canopies, that is the thickness of the main branches is decreasing from the upper region to the higher parts. Some cultivars presented different tendency. The higher and the middle zone $(150-250 \mathrm{~cm})$ of the cvs 'Fengal' and 'Fendeca' canopy is built up with similar thick branches. Besides in the higher parts of the cv 'Red Jonaprince' trees the branches can

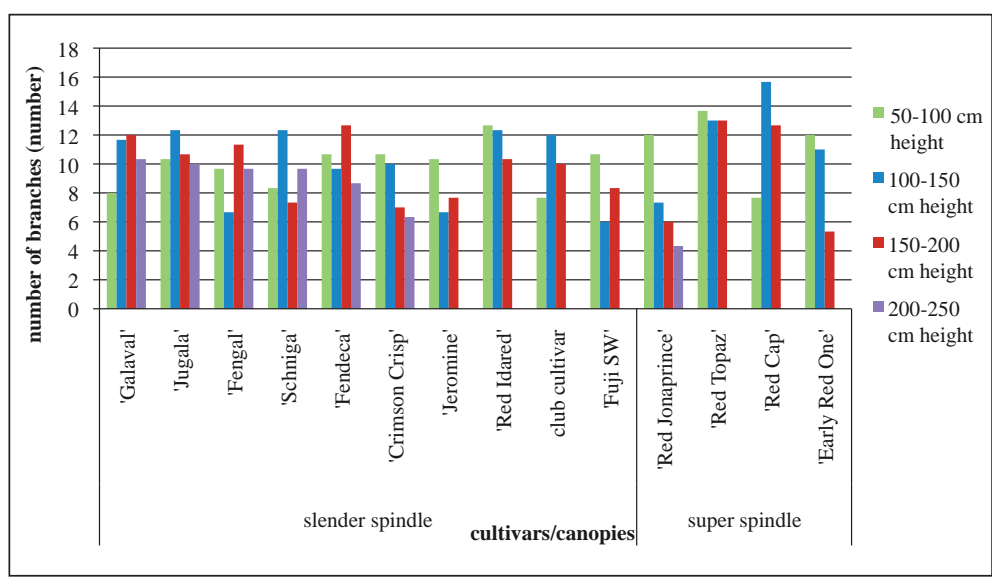

Figure 3: Number of the branches in different height zones of the central leader (Nyírbátor, 2014).

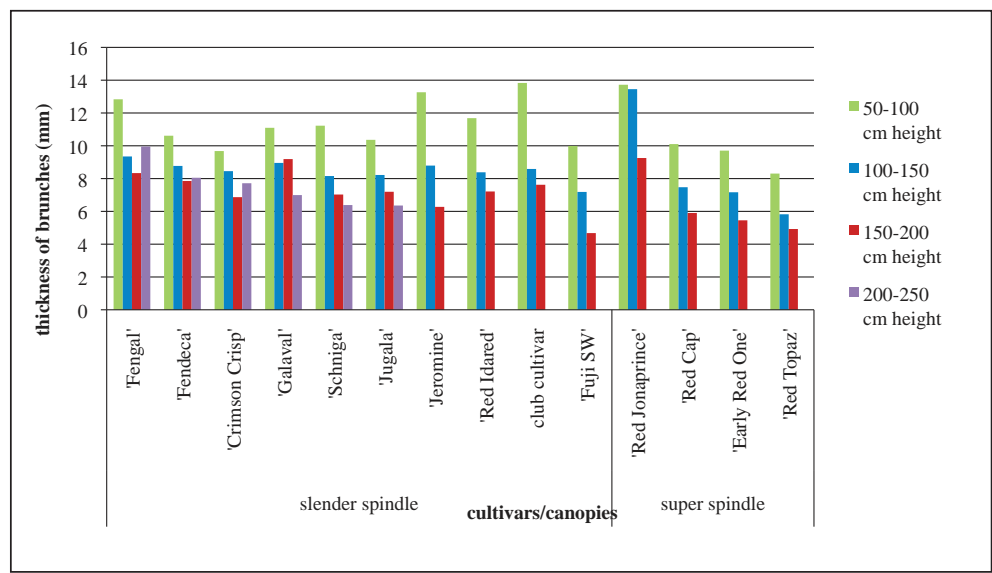

Figure 4: Thickness of the branches in different height zones of the central leader (Nyírbátor, 2014).

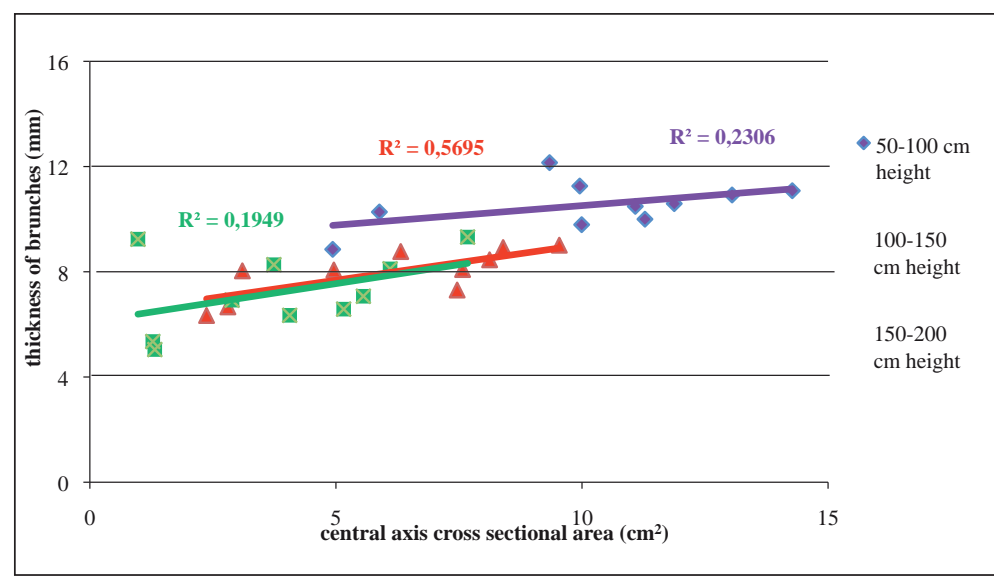

Figure 5: Relationship between the tapering dynamics of the central leader and the thickness of the main branches in slender spindle canopy (Nyírbátor, 2013). be too thick. Considering the fact, that this cultivar showed also lower ramification in the higher zones, the maintaining the optimal canopy structure of the super spindle trees needs more attention.

Regarding the canopies relationship was found between the tapering dynamics of the central leader and the thickness of the main branches (Figures 5 and 6). In the case of the $\left.-R^{2}=0.56\right)$, than on super spindle $\left(R^{2}=0.54-\right.$ $\mathrm{R}^{2}=0.63$ ). Based on this the next tendency is stronger on the super spindle canopies, than on the super spindle trees: the thickness of the branches decreases in proportion to the tapering dynamics of the central leader by going from the upper regions to the higher zones. 


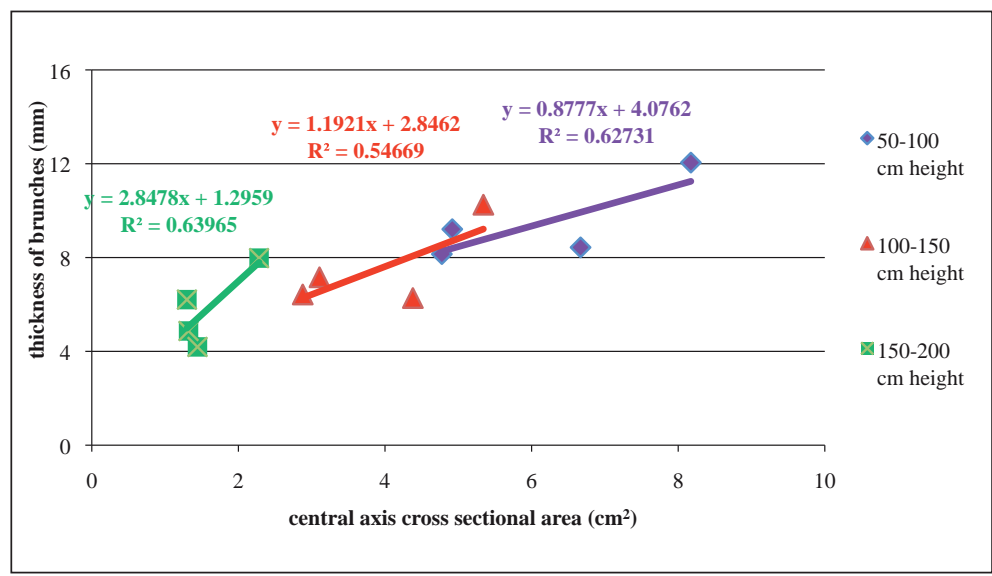

Figure 6: Relationship between the tapering dynamics of the central leader and the thickness of the main branches in super spindle canopy (Nyírbátor, 2013)

\section{Conclusions}

The main branches of the trunk and the central leader tend to over thickening in the case of cvs 'Red Idared', 'Wilton's Red Jonaprince' and 'Jeromine'. To prevent this negative phenomenon, thus maintain the branches specific fitotechnical interventions (bending down, cambering, cracking) are suggested to carry out during the training of the canopy.

The density of the branches of certain parts of the canopy was too low for cvs 'Crimson Crisp', 'Wilton's Red Jonaprince', 'Fuji September Wonder' and 'Red Idared'. In the case of these cultivars the increasement of the budding is required by pruning and other fitotechnical interventions (nicking above the bud).

The density of the branches of certain parts of the canopy was too high for cvs 'Gala Venus Fengal', 'Wilton's Red Jonaprince' and 'Red Cap Valtod'. The optimal density and light penetration of the canopy must be created with regular thinning pruning.

Relationship was found between the tapering dynamics of the central axis and the thickness of the main branches, which was stronger in super spindle canopies than in slender spindle crown forms. That means the possibility of the easier maintenance of the super spindle trees.

\section{Acknowledgements}

This research was supported by grants of the Hungarian Scientific Research Fund (K108333).

\section{References}

Corelli, L., Sansavini, S. (1989): Light management and photosynthesis related to planting density and canopy management in apple. Acta Hort. 243: 159-174.

Gonda, I. (1995a): Az intenzív almatermesztés hazai tapasztalatai és perspektívái. Új Kertgazdaság 1 (3): 62-64.

Gonda I. (1995b): Az intenzív almatermesztés koronaformái. [In: Kiút a válságból. Intenzív almatermesztés. Szerk.: Gonda, I.] PRIMOM Kiadó, Nyíregyháza. 81-89.

Gonda I. (1997): Művelési rendszer, fitotechnika. [In. Integrált gyümölcstermesztés. Szerk.: SOLTÉSZ, M.] Mezőgazdasági Kiadó, Budapest. 438-449.

Gonda I. (2004): Almaültetvények müvelési rendszereinek és koronaformáinak fejlődése hazánkban. [In: A gyümölcsök termesztése. Szerk.: PAPP, J.] Mezőgazda Kiadó, Budapest. 56-62.

Gonda I., Fülep, I. (2011): Az almatermesztés technológiája. Debreceni Egyetem AGTC Kutatási és Fejlesztési Intézet, Gonda István Betéti Társaság, F. N. Fruit Kft. 260. pp.

Weber, M. S. (1998): The Super Spindle System. Acta Hort. 513: 271-278.

Wertheim, S. I. (1968): The training of the slender spindle, Proestaliton Voor de Fruittelt, Wilhwlminadorp. Bul. 7.

Zahn, F. G. (1975): Mabstabe für die Anzucht und den Schnitt der Obstgehölze. Mitteilungen des OVR Jork 30: 93-109. 